ponderance of analytical rather than synthetic or creative work, a tendency to measure an effect rather than to make use of it; new courses, especially, say, those of the Sevenoaks type, can be more properly regarded as introduced to redress this lack of balance. 'This kind of response may automatically help to foster the kinds of attitude one would look for in successful engineers, but has not specifically been introduced for this purpose.

Yet, secondly, a good deal of play is made of the reluctance of headmasters to accept that the "alternative road' into a scientific career might be the best one for some of the best students. This necessarily brings to mind many thoughts about educational attitudes in the country, and the concern of engineers with their own 'public image', especially in the eyes of soience teachers counselling boys and girls when they consider university courses. If one considers the diversity of activities under the broad head of engineering and technology, it is perhaps not too surprising that this image is a little out of focus, but the present careful expositions of the need for flexibility, breadth and social and economic awreness in an engineer may alter this. If a teacher is able to consider an engineer as a bridge-builder between two cultures, rather than a glorified technician, he can then be more inclined to satisfaction at the prospect of the best intellects entering engineering careers. The objections by a number of authorities to the idea of A-Level examinations in applied science make good sense when one considers the present-day attempts to ask for more flexible university entrance requirements, and the talk of a single chemistry- physics A-Level subject. At the same time, the investigations of approaches to technological studies at sixthform level and the centralization of such work by the Schools Council are very welcome. What seems vital is that any teaching institution should be concerned, within the general framework of science courses which its size and resources allow it to offer, to present as wide a picture of what the whole effort of scientific and technological work consists of, as is possible, whether this be through complete courses in large schools, or project work, or re-orientation of existing pure science into application-conscious treatment. This is particularly true, if like the Nuffield. Scheme co-ordinator, one regards a sixth-form course as being a final chance to sample disciplines; it will be of very great interest to see the eventual content of the Nuffield A-Level courses. Help which can be obtained, through curriculum research of any kind, for example, is obviously most important in all circumstances.

In any event, the Page Report, making available detailed information, opinion and informed suggestion, is a key document for anyone concerned in decisions about school science courses. In addition, it is eminently readable, and, despite the rapidity of its publication, excellently produced. It is possible that it may be the preliminary to further substantial changes in school work, and it will certainly help the careful thinking about this rather complex subject which is needed while school science is altering at the present rapid rate.

\section{T. A. BURDETT}

\title{
CHEMICAL PHYSIOLOGY OF THE ACID MUCOPOLYSACCHARIDES
}

$\mathrm{A}$ LTHOUGH there have been several excellent symposia on connective tissues, it is now too big a subject to cover adequately in a meeting of manageable size, and its various compartments tend to be treated separately. The acid mucopolysaccharides have been quite fully discussed from the metrobolic and chemical aspects, but not often from the point of view of the chemical physiologist. This is not surprising, since the state of combination of acid mucopolysaccharides in tissues was unknown, their localization dependod on primitive and non-specific techniques, and practicaliy nothing was known of their molecular biology. Considerable progress is being made on all three problems, and it was thought that the results would support a three-day meeting, with ample discussion.

The symposium was organized by Dr. Giuliano Quintarelli, of the University of Alabama, and held under the auspices of the Carlo Erba Foundation in Milan during September 23-25. Travel grants wero made available by American Chicle Co. and Colgate-Palmolive Co. through Dr. J. Volker, vice-president of the University of Alabama Medical Center.

Seventeen speakers were invited, several of whom comprehensively reviewed their subjects in addition to presenting new data. Dr. Helen Muir (St. Mary's Hospital, London) opened the proceedings with a paper on "Protein-Polysaccharides", and was followed by Dr. L. Rodén (University of Chicago) on "The Protein-Carbohydrate Linkages of Acid Mucopolysaccharides". Dr. Rodén presented the evidence that chondroitin sulphate $A$ is linked to protein by means of a glucuronosyl-galactosylgalactosyl-xylosyl-serine bridge, with much detail on positions of glycosidic bonds, etc. Dr. P. Hoffman (Research Institute for Skeletomuscular Diseases, New York) discussed threonine, serine and asparagine as alternative linkage points for the polysaccharide at the protein. Dr. Hoffman took up a theme introduced by Dr. Muir (frequently mentioned during the meeting) as to how heterogeneous the cartilage protein-polysaceharide is, and showed that his preparations contained chemically dissimilar fractions, separable on electrophoresis.

Papers by Dr. Castellani (Pavia) and Drs. Pedrini and Pedrini-Mille (University of Iowa) dealt with the keratansulphate-protein complex from epiphyseal plates and human costal cartilage, respectively. Dr. Pedrini reported three components in his water extracts, as shown by electrophoresis on cellulose acetate, the slowest being predominantly the keratansulphate complex, and the fastest the chondroitin sulphate complex. The ratio of the slowest to the fastest increased with age. They differed significantly in their amino-acid content. Dr. J. D. Gregory (Rockefeller University, New York) described countercurrent fractionation of the hyaluronidase digested cartilage protein-polysaccharide. Two components were isolatod, one containing the keratansulphate, and the other remnants of chondroitin sulphate attached to protein. Dr. N. di Ferrante (University of Texas), in the course of $a$ review of the "Antigenicity of the Protein Polysaccharide Complexes from Cartilage", presented evidence that the keratansulphate-protein fragment of Dr. Gregory possessed the antigenic properties of the original proteinpolysaccharide. The second fraction of Dr. Gregory, containing remnants of chondroitin sulphate, was not antigenic.

The papers of Dr. S. M. Partridge (Low 'Temperature Rosearch Station, Cambridge) and Dr. D. Dziewiatkowski (Rockefeller University, Now York) dealt with the effects and the isolation, respectively, of an enzyme present in cartilage which proteolytically degrades the proteinpolysaccharide. The implications of these findings to the study of tho complex are great, and probably much of the work already done will have to be reassessed. Dr. Cifonelli (University of Chicago) rounded off this section by pointing out areas in which chemical investigations had turned up conflicting data, and discussed degradative techniques which could resolve the difficulties.

Dr. T. C. Laurent (University of Uppsala, Sweden) opened the 'molecular biology' section with a demon- 
stration of the importance of the 'excluded volume' and 'available volume' concepts in this field. The interpretation of the physiological role of the acid mucopolysaccharides is likely to draw heavily on this work. Dr. E. A. Balazs (Retina Foundation, Boston) considered the role of polyanions in the transformation of chemical to mechanical energy in a paper entitled "The Mechanochemical Function of Mucopolysaccharides in the Organization of the Intercellular Matrix". Dr. J. E. Scott (Taplow, England) reviewed. "Ion Binding in Solutions containing Acid Mucopolysaccharides" and suggested that Coulombic complexes of proteins and acid mucopolysaccharides could be 'ion-buffers'. Work on the "Interaction of Collagen and Acid Mucopolysaccharides" was presented by Dr. M. B. Mathews (University of Chicago).

The mierolocalization section was introduced by Dr. G. Quintarelli (University of Alabama) in a review of relevant histochemistry which demonstrated that little reliance could be placed on previously accepted techniques. Dr.
J. E. Scott (Taplow, England) described how the "critical electrolyte concentration" phenomenon could be used to investigate and improve on the specifieity of cationic dyes. In the final paper, Dr. S. Gardell (University of Lund, Sweden) compared the results of the best available mucopolysaccharide fractionation techniques for the analysis of microgram quantities of tissues obtained by microdissection.

The chairman of the concluding session, Dr. E. A. Balazs, thanked the organizers and particularly Dr. Sirtori and the Carlo Erba Foundation for their magnificent hospitality; the participants joined in complete agreement. This was the first full three-day symposium in English to be held at the Carlo Erba Foundation, and everyone present will wish for the opportunity to be present at others in the future.

The Proceedings will be edited by Dr. Quintarelli and published in book form by Little and Brown, Boston.

J. E. Scotr

\title{
POSSIBLE CONTRIBUTION OF JUPITER'S MAGNETOSPHERIC TAIL TO THE RADIO EMISSIONS OF THE PLANET IN THE DECAMETRIC REGION
}

\author{
By G. M. GRUBER \\ Department of Physics, Rhodes University, Grahamstown, South Africa
}

$S^{\mathrm{n}}$ INCE Bigg ${ }^{1}$ showed that the satellite Io influences the decametric emission it seemed promising to look for dependences which are not related to the rotation of the planet Jupiter. Prof. J. A. Gledhill suggested to me that it might be interesting to investigate the possibility that radiation from Jupiter's magnetospheric tail contributes towards the decametric noise.

Since the data obtained at our research station were insufficient for any large-scale investigation, the obvious choice was the data of J. W. Warwick and W. T. Kreiss ${ }^{2}$ compiled from obsorvations during January I, 1960Decermber 31, 1963. In addition, Drs. Warwick and Dulk supplied me with the data obtained during January 1, 1964-May 31, 1965, for which I thank them.

In their data they recorded the U.T. start and finish of each observing period and of each Jupiter event, its frequency range, intensity (on a scale of 1,2 and 3 ), the burstiness as weak, moderate or strong, and the System III cML (Central Meridian Longitude) of each event.

To find whether any influence of the magnetospheric tail existed, the following procedure was adopted. The period between two superior conjunctions was divided into 27 intervals each of 15 days, except for the first and the last which have less than 15 days. The intervals were numbered from -13 to +13 ; interval 0 was centred on the day of opposition. For each of these intervals the total time for which Jupiter was observed was computed as well as the total time during which Jupiter events occurred. The ratio of the latter to the former gives the percentage probability of occurrence for that particular interval. (No notice was taken of the frequeney distribution of the bursts.) The number of events during the five apparitions woro $57,247,354,429$ and 229 respectively. The results for each apparition are shown in Figs. 1-5.

On combining the values for the five apparitions, that is, calculating the average percentage probability for correspondingly numbered intervals, a most interesting result is obtained (Fig. 6).

From the graph it appears that the percentage probability of observing docametrie emission is much higher before opposition than after opposition, the ratio being approximately $3: 2$. Furthermore, a sudden 'cut-off' after opposition is evident.
G. A. Dulk ${ }^{3}$ has drawn up histograms for the first and second half of the apparitions of 1963 and 1964. The higher probability of occurrence is quite noticeable, and he suggested that the difference might be attributed to the

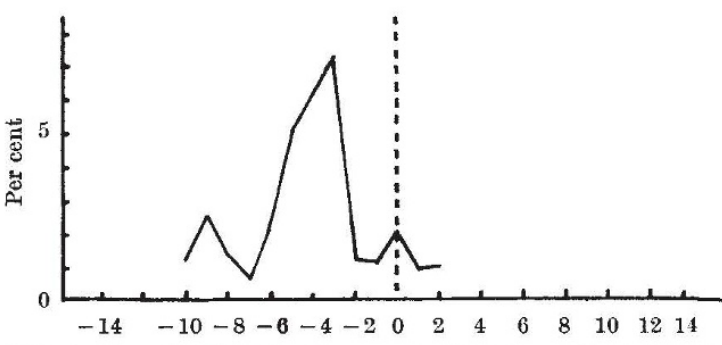

Fig. 1. Percentage probability versus interval number for 1960

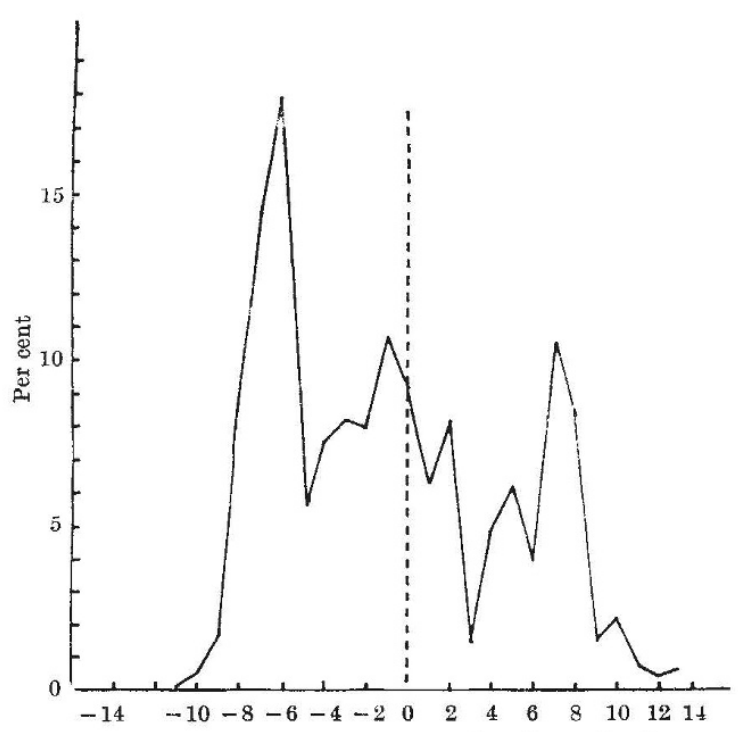

Fig. 2. Percentage probability versus interval number for 1961 